\title{
Pengaruh Pemberian Tuntunan Penyelesaian Latihan Soal Dalam Pembelajaran Langsung Terhadap Peningkatan Pemahaman Konsep Pereaksi Pembatas Pada Siswa Kelas X SMA Negeri 4 Palangka Raya Tahun Ajaran 2018/2019
}

\author{
Shela Parandika ${ }^{1} *$ Abudarin $^{1}$, Karelius ${ }^{2}$ \\ ${ }^{1}$ Program Studi Pendidikan Kimia, Universitas Palangka Raya, Indonesia \\ ${ }^{2}$ Program Studi Kimia, Universitas Palangka Raya, Indonesia \\ *E-mail: shelaandroid@gmail.com
}

\begin{abstract}
Abstrak
Tujuan dari penelitian ini adalah untuk menjelaskan pengaruh pemberian tuntunan penyelesaian latihan soal dalam pembelajaran langsung terhadap pemahaman konsep perhitungan pemhaman konsep pereaksi pembatas pada siswa kelas X MIA SMA Negeri 4 Palangka Raya tahun ajaran 2018/2019.

Jenis penelitian ini adalah penelitian kuantitatif. Melalui penelitian ini, peneliti melakukan eksperimen dengan menentukan sampel untuk kelas kontrol dan kelas eksperimen, dalam penelitian ini melibatkan 65 siswa kelas X MIA SMA Negeri 4 Palangka Raya tahun ajaran 2018/2019. Instrumen yang digunakan berupa soal tes pemahaman kosep yaitu tes I dan tes II, dan latihan soal dengan tuntunan penyelesaian yang dikemas dalam bentuk lembar kerja yang berisi langkah-langkah penyelesaian soal.

Hasil penelitian ini menunjukkan bahawa terdapat perubahan pemahaman konsep siswa yang menerima pembelajaran menggunakan latihan soal dengan tuntunan penyelesaian. Hasil uji hipotesis $t_{\text {hitung }}=1,72$ dan $t_{\text {tabel }}=1,67$ dengan $\mathrm{db}$ $=\mathrm{n}_{1}+\mathrm{n}_{2}-2=65$ dengan taraf signifikan 5\%, artinya hasil $\mathrm{t}_{\text {hitung }}>\mathrm{t}_{\text {tabel }}$ sehingga $\mathrm{H}_{\mathrm{o}}$ ditolak dan $\mathrm{H}_{\mathrm{a}}$ diterima, sehingga dapat ditarik kesimpulannya pemberian tuntunan penyelesaian latihan soal dalam pembelajaran langsung berpengaruh terhadap pemahaman konsep pereaksi pembatas pada siswa kelas X MIA SMA Negeri 4 Palangka Raya tahun ajaran 2018/2019.
\end{abstract}

Kata Kunci: Pengaruh, Pereaksi Pembatas, Latihan Soal, Pemahaman Konsep 


\section{Pendahuluan}

Sifat ilmu kimia berurutan dan berkembang dengan cepat, sehingga topiktopik kimia harus dipelajari dengan urutan tertentu. Misalnya, kita tidak dapat menggabungkan atom-atom untuk menjadi molekul, apabila atom dan karakteristiknya tidak dipelajari terlebih dahulu. Perkembangan ilmu kimia sangat cepat, seperti pada bidang biokimia yang menyelidiki tentang rekayasa genetik, kloning dan sebagainya. Hal ini menuntut semua pihak untuk lebih cepat tanggap dan selektif dalam menerima semua perkembangan ilmu kimia. Penelitian yang dilakukan oleh Yopita (2013) tentang kesulitan siswa dalam memahami konsep materi perhitungan pereaksi pembatas diperoleh persentase dalam menuliskan reaksi sebesar $67 \%$ untuk penyetaraan sebesar $86 \%$. Kemudian untuk menentukan pereaksi pembatas dalam persamaan reaksi diperoleh persentase $28 \%$ berdasarkan penelitian yang diperoleh siswa mengalami kesulitan pada penulisan persamaan reaksi kimia dan menentukan pereaksi pembatas.

Proses belajar mengajar merupakan proses komunikasi aktif dalam kegiatan pembelajaran. Suatu proses belajar mengajar dapat dikatakan baik apabila proses tersebut dapat membangkitkan kegiatan belajar dengan melibatkan peserta didik secara emosial dan intelektual dalam proses belajar mengajar. Kimia berkaitan dengan keingintahuan dan memahami alam secara sistematik, sehingga kimia bukan hanya kumpulan yang berupa fakta-fakta, konsep-konsep, prinsipprinsip, tetapi juga merupakan suatu proses penemuan. Pendidikan kimia diharapkan dapat menjadi wahana bagi siswa untuk mempelajari alam sekitarnya.

Tujuan penelitian ini adalah untuk menguji perbedaan pengaruh pemberian latihan soal yang dilengkapi tuntunan penyelesaian dan latihan soal tanpa 
tuntunan penyelesaian dalam pembelajaran langsung terhadap peningkatan pemahaman konsep peraksi pembatas pada siswa kelas X SMA Negeri 4 Palangka Raya tahun ajaran 2018/2019.

Menurut Slemeto (2003), belajar adalah suatu proses usaha yang dilakukan seorang untuk memeproleh perubahan tingkah laku yang baru secara keseluruhan, sebagai hasil pengalamannya sendiri dalam interaksi dengan lingkungannya. Sementara menurut Gagne dalam Dahar (2011), belajar dapat didefinisikan sebagai suatu proses dimana suatu organisasi berubah perilakunya sebagai akibat pengalaman.

Konsep adalah suatu abstraksi yang mewakili suatu kelas objek, kejadian, kegiatan, atau hubungan yang mempunyai komponen yang sama. (Dahar, 1989), belajar konsep merupakan hasil utama dalam pendidikan. Konsep merupakan suatu abstraksi yang terbentuk dari observasi tentang perilaku-perilaku tertentu pada anak-anak. Konsep digunakan siswa untuk membedakan atau membuat hubungan dengan konsep lainnya membentuk pengetahuan ilmu kimia yang lebih kompleks (sempurna). Kegunaan konsep adalah untuk menjelaskan dan meramalkan (Dahar, 1989).

Pembelajaran langsung dirancang untuk mengenalkan siswa terhadap mata pelajaran guna membangun minat, menimbulkan rasa ingin tahu, dan merangsang siswa berpikir (Amri, 2010). Menurut Annurahman (2010), pembelajaran langsung adalah suatu model pembelajaran dimana kegiatan terfokus pada aktivitas-aktivitas akademik sehingga dalam implementasi kegiatan pembelajaran, guru melakukan kontrol yang ketat terhadap kemampuan belajar siswa, dan pendayagunaan waktu, serta situasi kelas. 
Penggunaan latihan soal dengan tuntunan penyelesaian sangat cocok digunakan pada materi-materi kimia yang bersifat prosedural, karena terbukti efektif untuk meningkatkan pemahaman konsep siswa. Argumen tersebut telah dibuktikan dengan adanya beberapa penelitian terdahulu yang menggunakan latihan soal dengan tuntunan penyelesaian terhadap materi yang memerlukan langkah-langkah dalam penyelesaian soal. Merdiana (2017) melakukan penelitian tentang pengaruh penggunaan latihan soal denga tuntunan penyelesaian terhadap pemahaman konsep pereaksi pembatas pada siswa kelas XI IPA SMA Negeri 1 Kahayan Hilir tahun ajaran 2016/2017. Hasil pembelajaran menggunakan latihan soal dengan tuntunan penyelesaian dalam mempelajari pereaksi pembatas meningkatkan pemahaman siswa menjadi 88,8\%. Penelitian dilakukan oleh Meilina (2015) tentang pereaksi pembatas, menunjukkan bahwa kemampuan siswa memahami pereaksi pembatas dengan pembelajaran menggunakan LKSDeduktif meningkat menjadi $70,6 \%$.

Materi pereaksi pembatas adalah materi yang dianggap sulit oleh siswa, dimana banyak siswa yang mengalami kesulitan dalam halnya menyetarakan reaksi dan menetukan mana yang digunakan sebagai pereaksi pembatas. Materi ini efektif bila diajarkan dengan menggunakan pemberian tuntunan penyelesaian latihan soal. Materi pereaksi pembatas termasuk ke dalam jenis pengetahuan prosedural. Pemberian tuntunan penyelesaian latihan soal dirancang sedemikian rupa, sehingga dapat memudahkan siswa dalam menyelesaikan soal-soal. Pemberian tuntunan penyelesaian latihan soal ini memuat langkah-langkah penyelesaian soal yang dibuat secara sistematis yang diberikan kepada kelas eksperimen termasuk petunjuk dan arahan yang mempermudah siswa dalam 
menyelesaikan soal, dengan pemberian tuntunan penyelesaian soal pada lembar latihan soal diperoleh siswa dapat menyelesaiakan latihan soal dengan lebih baik dibandingkan dengan latihan soal yang tidak diberikan tuntunan penyelesaian soal.

\section{Metodologi Penelitian}

Jenis penelitian yang digunakan dalam penelitian ini adalah penelitian kuantitatif. Penelitian ini terbagi dalam dua kelas yaitu kelas eksperimen dan kelas kontrol. Kelompok eksperimen adalah kelas sampel yang diberikan perlakuan khusus yaitu dengan pembelajaran langsung yang menggunakan latihan soal dengan tuntunan, sedangkan pada kelas kontrol adalah kelas yang digunakan sebagai perbandingan yaitu pembelajaran langsung yang menggunakan latihan soal tanpa tuntunan. Metode penelitian yang digunakan dalam penelitian ini adalah metode eksperimen, karena dalam penelitian ini dilakukan suatu percobaan dengan memberikan perlakuan dan membandingkan pengaruh perlakuan tersebut terhadap suatu sampel yang dipilih. Pada penelitian ini kelas eksperimen mendapat perlakukan khusus, sedangkan kelas kontrol tidak mendapatkan perlakuan khusus kemudian dibandingkan hasil akhirnya. Kelas ekperimen diberikan latihan soal dengan tuntunan penyelesaian sedangkan kelas kontrol diberikan latihan soal tanpa tuntunan penyelesaian. Uji normalitas dimaksudkan untuk menguji normal atau tidaknya distribusi data pada sampel. Uji normalitas ini menggunakan cara SPSS untuk menghitung $N$-gain pada kelas eksperimen dan kelas kontrol dengan tujuan untuk mengetahui distribusi data yang akan diperoleh 
dari tes masing-masing kelas siswa tersebut. Dasar Keputusan Uji Normalitas Shapiro-Wilk.

Jika nilai sig. > 0,05 maka data berdistribusi normal.

Jika nilai sig. $<0,05$ maka data tidak berdistribusi normal.

Uji homogenitas digunakan untuk menguji apakah populasi penelitian mempunyai varian yang sama. Varian merupakan jumlah kuadrat semua deviasi nilai-nilai individual terhadap rata-rata kelompok. Dari masing-masing kelompok dihitung nilai variannya $\left(S^{2}\right.$ dan $\left.S_{2}^{2}\right)$, setelah didapatkan nilai $S^{2}{ }_{1}$ dan $S_{2}^{2}$, pengujian homogenitas varian menggunakan uji $\mathrm{F}$ dengan rumus sebagai berikut:

$$
F=\frac{\text { varian terbesar }}{\text { varian terkecil }}
$$

Keterangan: $\mathrm{F}=$ koefisien $\mathrm{F}$ tes

Kriteria pengujian adalah membandingkan harga $\mathrm{F}_{\text {hitung }}$ dengan $\mathrm{F}_{\text {Tabel }}$ pada taraf signifikan $5 \%$ dengan dk pembilang dan penyebut $=\mathrm{n}_{1}-1$ yaitu:

- $\quad$ Jika harga $F_{\text {hitung }} \leq \mathrm{F}_{\text {Tabel }}$ maka data tersebut homogen.

- $\quad$ Jika harga $F_{\text {hitung }}>F_{\text {Tabel }}$ maka data tersebut tidak homogen.

Hipotesis merupakan jawaban sementara terhadap rumusan masalah penelitian. Ada 2 macam hipotesis statistik dalam penelitian ini yaitu hipotesis nol $\left(\mathrm{H}_{0}\right)$ dan hipotesis kerja $\left(\mathrm{H}_{\mathrm{a}}\right)$ yang berbunyi:

$\mathrm{H}_{0}=$ Tidak terdapat perbedaan pengaruh pemberian latihan soal yang dilengkapi tuntunan penyelesaian dan latihan soal tanpa tuntunan penyelesaian dalam pembelajaran langsung terhadap peningkatan pemahaman konsep pereaksi pembatas pada siswa kelas X SMA Negeri 4 Palangka Raya tahun ajaran 2018/2019. 
$\mathrm{Ha}=$ Terdapat perbedaan pengaruh pemberian latihan soal yang dilengkapi tuntunan penyelesaian dan latihan soal tanpa tuntunan penyelesaian dalam pembelajaran langsung terhadap peningkatan pemahaman konsep pereaksi pembatas pada siswa kelas X SMA Negeri 4 Palangka Raya tahun ajaran 2018/2019.

$$
\begin{aligned}
& \mathrm{H}_{0}: \mu_{1}=\mu_{2} \\
& \mathrm{H}_{\mathrm{a}}: \mu_{1} \neq \mu_{2}
\end{aligned}
$$

keterangan:

$\mu_{1}=$ Rata-rata nilai $\mathrm{N}$-gain siswa pada materi pereaksi pembatas hasil pembelajaran menggunakan latihan soal dengan tuntunan penyelesaian $\mu_{2}=$ Rata-rata nilai $\mathrm{N}$-gain siswa pada materi pereaksi pembatas hasil pembelajaran menggunakan latihan soal tanpa tuntunan

Untuk menguji hipotesis tersebut digunakan uji-t, rumus uji-t yang digunakan adalah sebagai berikut:

$$
\mathrm{t}=\frac{\bar{X}_{e}-\bar{X}_{k}}{\sqrt{\frac{\left(n_{e}-1\right) s_{e}^{2}+\left(n_{k}-1\right) s_{k}^{2}}{n_{e}+n_{k}-2}\left(\frac{1}{n_{k}}+\frac{1}{n_{e}}\right)}}
$$

keterangan: $\mathrm{t}=$ signifikan koefisien

$\bar{X}_{e}=$ rata-rata kelas eksperimen

$\bar{X}_{k}=$ rata-rata kelas kontrol

$\mathrm{n}_{\mathrm{e}}=$ jumlah sampel di kelas eksperimen

$\mathrm{n}_{\mathrm{k}}=$ jumlah sampel kelas kontrol

$S_{e}^{2}=$ simpangan baku eksperimen

$S_{k}^{2}=$ simpangan baku kelas kontrol 


\section{Hasil Penelitian Dan Pembahasan}

Pelaksanaan simulasi pembelajaran dilaksanakan di SMA Negeri 4 Palangka Raya pada kelas X MIA 2 dan X MIA 4 pengambilan data menggunakan dua kelas sampel. Kedua sampel tersebut adalah X MIA 1 sebagai kelas kontrol dengan jumlah siswa 34 orang dan X MIA 3 sebagai kelas eksperimen dengan jumlah siswa 33 orang. Berdasarkan wawancara dengan guru bidang studi kimia diketahui bahwa kedua kelas tersebut homogen, artinya kedua kelas memiliki kemampuan yang sama.

Deskripsi data pemahaman konsep siswa terdiri dari tes I dan tes II. Data nilai tes digunakan untuk mengetahui hasil perlakuan yang diberikan, dengan dilakukannya uji N-gain. Selain itu juga digunakan untuk mengetahui pengaruh penggu-naan latihan soal dengan tuntunan penyelesaian terhadap pemahaman siswa. Pelaksanaan tes I dan tes II dilakukan dengan waktu yang sama dengan jumlah masing-masing tes berisi 3 butir soal esai.

Setelah pembelajaran langsung, didapatkan data rata-rata tes I kelas eksperimen sebesar 30,68 dan setelah diberikan latihan soal dengan tuntunan penyelesaian, didapatkan data rata-rata tes II kelas eksperimen sebesar 70,27. Hal ini menunjukkan peningkatan rata-rata siswa kelas eksperimen sebesar 39,59.

Nilai tes I kelas eksperimen terendah adalah 12,50 dan tertinggi adalah 81,25. Rata-rata nilai tes I sebesar 30,68. Nilai tes II kelas eksperimen terendah adalah 40,74 dan tertinggi adalah 100. Rata-rata nilai tes II sebesar 70,27.

Setelah pembelajaran langsung, didapatkan data rata-rata tes I kelas kontrol sebesar 29,23 dan setelah diberikan latihan soal dengan tuntunan 
penyelesaian, didapatkan data rata-rata tes II kelas kontrol sebesar 63,79. Hal ini menunjukkan peningkatan rata-rata siswa kelas eksperimen sebesar 34,56.

Nilai tes I kelas kontrol terendah adalah 6,25 dan tertinggi adalah 81,25. Rata-rata nilai tes I sebesar 29,23. Nilai tes II kelas kontrol terendah adalah 31,25 dan tertinggi adalah 100,00. Rata-rata nilai tes II sebesar 63,79.

Berdasarkan informasi yang sudah disampaikan oleh guru mata pelajaran kimia SMA Negeri 4 Palangka Raya dan rata-rata hasil ulangan tengah semester, sebelum dilakukan pengambilan data diketahui bahwa kemampuan yang dimiliki oleh kelas eksperimen dan kelas kontrol tidak berbeda secara signifikan. Hal ini terbukti dengan hasil perhitungan uji normalitas dan homogenitas data $\mathrm{N}$-gain pada kedua kelas sampel.

Perhitungan Normalitas data yang diperoleh kemudian diolah menggunakan SPSS 25 untuk menunjukkan nilai signifikansi $\mathrm{N}$-gain kedua kelas sampel. Nilai signifikansi diperoleh dengan uji analisis Shapiro-Wilk, dengan signifikansi 0,74 untuk kelas eksperimen dan signifikansi 0,69 untuk kelas kontrol Hasil perhitungan uji normalitas N-Gain yang menunjukan kelas eksperimen dan kelas kontrol yaitu sig $>\alpha_{(0,05)}$, maka dapat disimpulkan data Ngain kelas eksperimen dan kontrol berdistribusi normal.

Uji homogenitas ini menggunakan rumus Fisher $(\mathrm{F})$. Kriteria pengujian adalah membandingkan $\mathrm{F}_{\text {hitung }}$ dengan $\mathrm{F}_{\text {Tabel }}$ pada signifikan 5\% dengan derajat kebebasan (n-1). Berdasarkan hasil perhitungan dari data kelas eksperimen dan kelas kontrol diperoleh $\mathrm{F}_{\text {hitung }}=1,01$ sedangkan $\mathrm{F}_{\text {Tabel }}=1,79$ (Perhitungan ada pada Lampiran14 halaman 119 ), karena $\mathrm{F}_{\text {hitung }}<\mathrm{F}_{\text {Tabel, }}$, maka dapat disimpulkan bahwa data tes I pada kelas eksperimen dan kelas kontrol dinyatakan homogen. 
Uji hipotesis pada penelitian ini menggunakan data rata-rata nilai tes I dan tes II kelas eksperimen dan kelas kontrol, data yang diperoleh menggunakan SPSS 25 untuk menunjukan nilai signifikan $\mathrm{N}$-gain kedua kelas sampel. Nilai signifikan diperoleh dengan uji analisis Shapiro-Wilk dengan signifikan untuk kelas eksperimen adalah 0,74 dan signifikan untuk kelas kontrol adalah 0,69

Ho = Perbedaan pengaruh pemberian latihan soal yang dilengkapi tuntunan penyelesaian dan latihan soal tanpa tuntunan penyelesaian dalam pembelajaran langsung tidak berpengaruh terhadap peningkatan pemahaman konsep pereaksi pembatas pada siswa kelas X SMA Negeri 4 Palangka Raya tahun ajaran 2018/2019.

$\mathrm{Ha}=$ Perbedaan pengaruh pemberian latihan soal yang dilengkapi tuntunan penyelesaian dan latihan soal tanpa tuntunan penyelesaian dalam pembelajaran langsung tidak berpengaruh terhadap peningkatan pemahaman konsep pereaksi pembatas pada siswa kelas X SMA Negeri 4 Palangka Raya tahun ajaran 2018/2019.

$$
\begin{aligned}
& \mathrm{H}_{0}: \mu_{1}=\mu_{2} \\
& \mathrm{H}_{\mathrm{a}}: \mu_{1} \neq \mu_{2}
\end{aligned}
$$

keterangan:

$\mu_{1}=$ Rata-rata nilai pemahaman konsep siswa pada materi pereaksi pembatas hasil pembelajaran menggunakan latihan soal dengan tuntunan penyelesaian (kelas eksperimen)

$\mu_{2}=$ Rata-rata nilai pemahaman konsep siswa pada materi pereaksi pembatas hasil pembelajaran menggunakan latihan soal tanpa tuntunan (kelas kontrol) 
Berdasarkan hasil perhitungan uji-t kedua kelas diproleh $t_{\text {hitung }}=1,72$ dan $\mathrm{t}_{\text {Tabel }}=1,67$ dengan $\mathrm{db}=\mathrm{n}_{1}+\mathrm{n}_{2}-2=65$ dengan taraf signifikan $5 \%$ (perhitungan lengkap dapat dilihat di halaman 58). Jadi diperoleh hasil $t_{\text {hitung }}>$ $t_{\text {Tabel }}$ sehingga $\mathrm{H}_{\mathrm{o}}$ ditolak dan $\mathrm{H}_{\mathrm{a}}$ diterima, sehingga dapat ditarik kesimpulannya yaitu Perbedaan pengaruh pemberian latihan soal yang dilengkapi tuntunan penyelesaian dan latihan soal tanpa tuntunan penyelesaian dalam pembelajaran langsung berpengaruh terhadap peningkatan pemahaman konsep pereaksi pembatas pada siswa kelas X SMA Negeri 4 Palangka Raya tahun ajaran 2018/2019.

\section{Simpulan}

Berdasarkan uji parametik menggunakn statistik menunjukkan bahwa terdapat perbedaan peningkatan pemahaman konsep hukum perbandingan tetap hasil pembelajaran menggunakan latihan soal dengan tuntunan penyelesaian dengan menggunakan latihan soal tanpa tuntunan penyelesaian pada siswa kelas $\mathrm{X}$ SMA Negeri 4 Palangka Raya. Rata-rata N-gain pada kelompok eksperimen $(0,72)$ lebih besar dari kelompok kontrol $(0,63)$.

Berdasarkan hasil penelitian, disarankan bahwa pembelajaran langsung menggunakan latihan soal dengan tuntunan penyelesaian dalam pembelajaran kimia dapat dijadikan salah satu alternatif pilihan untuk meningkatkan pemahaman konsep siswa. Namun, guru juga harus menyesuaikan dengan materi pelajaran, yaitu materi yang merujuk kepada materi yang penyelesaiannya menggunakan perhitungan. 
Shela Parandika (215-228)

\section{Daftar Referensi}

Amelia, F. 2018. Perbedaan Pemahaman Konsep Pereaksi Pembatas Hasil Pembelajaran Langsung Menggunakan LKS-Latihan Soal Terstruktur Dan LKS Latihan Soal Pada Siswa Kelas X SMA Negri 4 Palngka Raya Tahun Ajaran 2017/2018.Skripsi Sarjana.Tidak diterbitkan.Universitas Palangka Raya.

Amri, S. 2010. Proses Pembelajaran Inovatif dan Kreatif Dalam Kelas. Cetakan Pertama. Jakarta : Prestasi Pustakarya.

Annurrahman. 2010. Belajar dan Pembelajaran. Bandung: Alfabeta.

Arifin, M. 2003. Strategi Belajar Mengajar Kimia. Bandung : Universitas Pendidikan Indonesia.

Dahar, R.W. 2011. Teori-Teori Belajar dan Pembelajaran.Jakarta:Erlangga.

Hamdani. 2011. Strategi Belajar Mengajar.Bandung:CV Pustaka Setia.

Hakim, T. 2000. Belajar Secara Efektif, Jakarta : Puspa Swara.

Jauhar, M. 2011. Implementasi PAIKEM dari Behavioristik sampai Kontrukivisik: Sebuah Pemngembangan Pembelajaran Berbasis CTL (Contextual Teaching Learning). Jakarta: Prestasi Pustakarya

Mardiana, E. K. 2017. Pengaruh Penggunaan LKS- Terstruktur Terhadap Pemahaman Konsep Preaksi Pembatas Pada Siswa Kelas Xl SMA Negri 1 Kahayan Hilir Tahun Ajaran 2016/2017.Skripsi Sarjana.Tidak diterbitkan.Universitas Palangka Raya.

Melina, F. 2015. Pemahaman Konsep Preaksi Pembatas Hasil Pembelajaran Menggunakan LKS-Induktif Pada Siswa Kelas Xl SMA Negri 1 
Palangka Raya Tahun Ajaran 2016/2017.Skripsi Sarjana.Tidak diterbitkan.Universitas Palangka Raya.

Nurdin, S. \& Adriantoni. 2016. Kurikulum dan Pembelajaran. Jakarta: PT Raja Grafindo Persada.

Indrawan, R., \& Yaniawati, P. 2016. Metodologi Penelitian. Bandung: PT Refika Aditama

Poerwadarminta, W.J.S. 1999. Kamus Besar Bahasa Indonesia. Jakarta: Balai Pustaka.

Qadratilah, M., dkk. 2011. Kamus Bahasa Indonesia untuk Pelajar. Jakarta: Badan Pengembangan dan Pembinaan Bahasa.

Kountur, R. 2009. Metode Penelitian. Jakarta: Buana Printing.Majid, Abdul. 2005. Perencanaan Pembelajaran. Bandung: PT Remaja Rosdakarya Offset.

Pasini, M. J. 2017. Statistika Pendidikan Konsep \& Penerapannya Menggunakan Minitab dan Micsrosoft Excel. Yogjakarta: Penerbit ANDI.

Rachamawati, T., \& Daryanto. 2015. Teori Belajar dan Proses Pembelajaran yang Mendidik. Yogyakarta: Gava Media.

Riyanto, Y. 2010. Paradigma Baru Pembelajaran. Cetakan Ketiga. Jakarta: Kencana.

Rusman. 2012. Model-model Pembelajaran Mengembangkan Profesionalisme Guru Edisi Kedua. Bandung: PT. Raja Grafindo Persada.

Sagala, S. 2003. Konsep dan Makna Pembelajaran. Bandung: Alfabeta.

Sanjaya, W. 2013. Penelitian Pendidikan: Jenis, Metode, dan Prosedur. Bandung: PT. Fajar Interpratama Mandiri. 
Shela Parandika (215-228)

Suyono dan Hariyanto, M. 2011. Belajar dan Pembelajaran. Bandung : PT Remaja Rosdakarya. 